\title{
PENINGKATAN KUALITAS PELAYANAN IMB DALAM MENINGKATKAN PENDAPATAN ASLI DAERAH KOTA BOGOR DIWILAYAH KECAMATAN BOGOR TIMUR
}

\section{IMPROVING THE QUALITY OF IMB SERVICES IN IMPROVING THE ORIGINAL INCOME OF THE CITY OF BOGOR IN THE REGION OF BOGOR EAST DISTRICT}

\author{
Lulu Kristina1, Rita Rahmawati², Euis Salbiah ${ }^{3}$
}

\begin{abstract}
1Jurusan Ilmu Administrasi Negara Fakultas Ilmu Sosial dan Ilmu Politik Universitas Djuanda, Jl Tol Ciawi No 1, Kotak Pos 35 Bogor 16720.

2Jurusan Ilmu Administrasi Negara Fakultas Ilmu Sosial dan Ilmu Politik Universitas Djuanda, Jl Tol Ciawi No 1, Kotak Pos 35 Bogor 16720.

${ }^{3}$ Jurusan Ilmu Administrasi Negara Fakultas Ilmu Sosial dan Ilmu Politik Universitas Djuanda, Jl Tol Ciawi No 1, Kotak Pos 35 Bogor 16720.

aKorespondensi: Lulu Kristina. HP: 085215189330; E-mail: lulu.kristina@unida.ac.id
\end{abstract}

(Diterima Oleh Dewan Redaksi: 01-02-2018)

(Dipublikasikan Oleh Dewan Redaksi: 01-04-2018)

\begin{abstract}
Increasing public demand is a logical consequence of the increasingly complex needs of the community on various matters, especially on service. On the other hand in line with one of the paradigms of public administration, namely Public Service, government has an obligation to improve the quality of service that aims to the satisfaction of the community (driven customer).

The purpose of this research is to analyze the implementation of the service of IMB (Building Permit), especially apparatus or human resources in charge of granting permission in East Bogor Subdistrict and to know the implementation of Building Construction Permit (IMB) in increasing the Original Revenue in East Bogor District. The theory used in this research is service quality theory from Sinambela (2010) that is transparent, accountability, conditional, participative, equality of rights, balance of rights and obligation.

The method used is descriptive analysis and using qualitative approach. While the data analysis technique used is Weight Mean Score (WMS) and correlation coefficient of Spearman Rank. Data collection technique used is study of literature and field study. The unit of analysis of this study amounted to 30 Informants. While the sampling technique used is Accidental Sampling technique.

The results of the Implementation of the granting of Building Permit is comply with the Decision of the Governor of West Java Province No. 76 year of 2000 on the procedure of obtaining IMB, IPB and KMB in the province of West Java and West Java Provincial Regulation No. 7 of 2010 About Building Buildings.
\end{abstract}

Keywords: Quality of service, Building Permit (IMB), and Increased local revenue 


\begin{abstract}
ABSTRAK
Meningkatnya tuntutan masyarakat merupakan konsekuensi logis dari semakin kompleksnya kebutuhan masyarakat pada berbagai hal, terutama terhadap pelayanan. Pada sisi lain sejalan dengan salah satu paradigma penyelenggaraan pemerintah, yakni Public Service (pelayanan publik) pemerintah mempunyai kewajiban untuk meningkatkan kualitas jasa pelayanan yang bertujuan kepada kepuasan masyarakat (driven customer). Tujuan dari penelitian ini yaitu untuk menganalisis pelaksanaan pelayanan pemberian IMB (Izin Mendirikan Bangunan) khususnya aparatur atau sumber daya manusia yang membidangi pemberian izin di Kecamatan Bogor Timur dan Untuk mengetahui pelaksanaan pemberian Izin Mendirikan Bangunan (IMB) dalam meningkatkan Pendapatan Asli Daerah di wilayah Kecamatan Bogor Timur. Teori yang digunakan dalam penelitian ini yaitu dengan menggunakan teori kualitas pelayanan dari Sinambela (2010) yaitu transparan, akuntabilitas, kondisional, partisipatif, kesamaan hak, keseimbangan hak dan kewajiban. Metode yang digunakan adalah deskriptif analisis dengan menggunakan pendekatan Kualitatif. Sedangkan teknik analisis data yang digunakan yaitu dengan menggunakan perhitungan Weight Mean Score (WMS) serta koefisian korelasi rank spearman.Teknik pengumpulan data yang digunakan adalah studi kepustakaan dan studi lapangan. Unit analisis penelitian ini berjumlah 30 Informan. Sedangkan teknik sampling yang dipakai yakni teknik Accidental Sampling. Hasil penelitian Pelaksanaan pemberian Izin Mendirikan Bangunan dilakukan dengan mengacu Keputusan Gubernur Provinsi Jawa Barat No. 76 Tahun 2000 tentang tata cara memperoleh IMB, IPB dan KMB di provinsi Jawa Barat dan peraturan Daerah Provinsi Jawa Barat Nomor 7 Tahun 2010 Tentang Bangunan Gedung.
\end{abstract}

Kata Kunci: Kualitas pelayanan, Izin Mendirikan Bangunan (IMB), dan Peningkatan pendapatan asli daerah

Lulu, Kristina. 2017. Peningkatan Kualitas Pelayanan IMB dalam Meningkatkan Pendapatan Asli Daerah Kota Bogor Diwilayah Kecamatan Bogor Timur. Jurnal Governansi. 


\section{PENDAHULUAN}

Permasalahan yang timbul dari keluhan masyarakat adalah akibat kurangnya personil dalam melayani masyarakat. Hal tersebut dapat mengakibatkan lambannya penerbitan IMB dan akibatnya masyarakat enggan untuk melakukan pengurusan surat izin tersebut, bahwa keterbatasan pegawai merupakan hal yang menjadi dasar keterlambatan dari pihak masyarakatpun seharusnya dapat ditampung dan dapat diselesaikan dengan mengambil jalan solusi yang baik. Selain itu masyarakat sekarang pun sudah mengerti dengan media sosial maka dari itu masyarakat dapat memberikan masukan atau keluhan nya pada akses tersebut.

Dalam satu daerah mensejahterakan masyarakat juga adalah salahsatu tugas pokok pemerintah secara umum, yakni dengan memberi pelayanan pada masyarakat (Publice Service). Semakin dominan sarana dan prasarana yang diadakan pemerintah maka diharapkan bisa semakin maju daerah serta masyarakatnya. Contohnya yang memerlukan pelayanan publik dengan baik dan benar yaitu pelayanan dalam IMB (Izin Mendirikan Bangunan).

IMB erat korelasinya dengan pertahanan dan setiap warga Indonesia memiliki hak dalam memanfaatkan tanah baik untuk tempat tinggal maupun untuk bangunan sebagaimana tertuang dalam Undangundang Agraria No. 5 Tahun 1960, pasal 6 "Semua hak atas tanah mempunyai fungsi sosial" dan dalam Undang-undang dasar 1945 pasal 33 Ayat 3 (Hukum Agraria meliputi $\mathrm{H}$ pertanahan, $\mathrm{H}$ perairan, $\mathrm{H}$ pertambangan (kekayaan alam)". Disamping itu hukum yang berlaku diatas, air, bumi dan ruang ialah hukum adat selama tidak bertolakbelakang dengan urgensitas negara dan nasional.

Apa saja yang berbentuk sebuah izin adalah kebijakan pemerintah (KTUN) yang paling utama berhubungan dengan pengajuan permohonan dan penertibannya wajib disertakan syarat-syarat serta pertimbangan, dalam hal pengaturan proses perizinan mengalami prosedur yang berbeda-beda dari jenis perizinan lainnya, misalnya saja dalam proses perizinan mendirikan bangunan.

Dalam mendirikan bangunan Kota Bogor mengadakan pembangunan non fisik dan fisik, pembangunan fisik contohnya dibangunnya jembatan, jalan, gedung, perumahan, sekolah, dll. Sedangkan bangunan non fisik contohnya meningkatkan kualitas kesehatan, meningkatkan kualitas pendidikan, dll. Pembangunan yang dilaksanakan tanpa pemikiran dan perencanaan yang matang akan berefek negatif pada bangunan itu dan pada lingkungan sekitar, contoh pengaruh hal itu kepada lingkungan adalah terjadinya bencana alam (banjir), pencemaran, penurunan hasil pertanian, dll. Agar tidak terjadi permasalah-permasalahan demikian maka diperlukan adanya pengaturan.

Dari pemerintah sendiri yaitu dari pihak yang bekerja di Dinas Perizinan atau Dinas Pekerja Umum dan Perumahan, seringkali menunda agenda dalam menyampaikan perintah dari Walikota. Sehingga dampaknya terlambat dari waktu yang telah ditentukan sebelumnya, kemudian pemberian Izin Mendirikan Bangunan (IMB) selalu memerlukan prosedur birokrasi yang panjang dan berbelit-belit, masyarakat yang punya keinginan untuk mengurus IMB harus memiliki keterangan mulai dari RT, RW, Kelurahan, Kecamatan untuk memperoleh IMB yang panjang seperti ini tentunya banyak menyita energi masyarakat yang ingin mendapatkan IMB sedangkan dari masyarakatnya sendiri banyak masyarakatnya yang kurang akan kesadaran hukum dan kurangnya kebutuhan terhadap hukum yang berlaku sehingga terkadang masyarakat tak menghiraukan akan adanya IMB tersebut.

Sehubungan dengan hal tersebut diatas, maka ditetapkan dasar pengaturan IMB adalah Keputusan Pemerintah Daerah Jawa Barat Nomor 7 Tahun 2006 tentang pedoman Pemberian Izin Mendirikan bangunan dan Retribusi , Izin Mendirikan Bangunan (IMB) adalah perizinan yang 
diberikan oleh pemerintah daerah kepada pemohon untuk membangun baru, rehabiltas / renovasi, dan / memugar dalam rangka melestarikan bangunan sesuai dengan persyaratan teknis yang berlaku.

Setiap kegiatan pembangunan bangunan di wilayah Kota Bogor, masyarakat terlebih dahulu mengurus dan memperoleh izin Mendirikan bangunan sesuai dengan ketentuan yang berlaku. Hal ini dimaksudkan agar pembangunan tersebut berjalan dengan lancar dan tidak terjadi hal - hal yang tidak diinginkan dikemudian hari. Pada prinsipnya, IMB bertujuan agar terjadi keselarasan antara lingkungan dan bangunan. Selain itu, dengan IMB diharapkan agar bangunan yang akan dibangun aman bagi keselamatan jiwa penghuni nya. Hal ini diperkuat oleh hasil wawancara dengan camat Kecamatan Bogor Timur. Pemilik bangunan dalam membangun bangunan sering bertentangan dengan aturan yang berlaku, dalam hal ini tidak sesuaidengan rencana tata ruang. Pemilik bangunan berhadapan dengan masalah peruntukan lahan. Faktanya pemilik bangunan ketika ingin membangun bangunan di suatu lahan tetapi lahan tersebut diperuntukan sebagai resapan air sehingga lahan tersebut tidak mungkin untuk didirikan bangunan. Hal tersebut juga di ungkapan oleh Camat Bogor Timur. Masalah peruntukan lahan memang menjadi aturan yang sudah ditetapkan dalam pelaksanaan pemberian IMB, dimana lahan tersebut dianalisis sesuai dengan tujuan yaitu untuk menjamin keselamatan, kesehatan, kenyamanan bagi pemilik bangunan serta selaras dan serasi dengan lingkungan.

\section{Unit Analisis \\ MATERI DAN METODE}

Untuk mencari besar sampel memakai tabel penentuan jumlah sampel menurut Sugiyono 2007, berdasarkan tabel tersebut untuk populasi 42 orang besar sampelnya adalah 30 orang, sehingga sampel dalam penelitian ini adalah 3 orang yang terdiri dari Sekretaris Camat, Kepala Seksi, Kasubag dan Pelaksana di Kantor Kecamatan Bogor Timur dan warga masyarakat Bogor Timur serta masyarakat yang terdiri dari Wiraswasta, pegawai Swasta dan juga Pedagang.

\section{Teknik Pengumpulan Data}

Ada dua teknik yang dipakai untuk pengumpulan data dari tulisan ini yakni teknik pengumpulan data dengan studi kepustakaan serta dengan studi lapangan. Studi kepustakaan dilaksanakan dengan metode menelaah dan mempelajari berbagai bahanliteratur dan sumbersumber tertulis lainnya seperti: artikel, buku, leteratur lainnya, yang berkaitandengan konsep serta teori teori tentang Izin mendirikan Bangunan. Sedangkan studi lapangan dilakukan guna memperoleh daa informasi yang berkenaan dengan pelaksanaan pelayanan dalam memberikan IMB (Izin Mendirikan Bangunan) di Kecamatan Bogor Timur.

Dalam studi lapangan, peneliti melaksanakan mengumpulkan data melalui daftar pertanyaan kepada beberapa narasumber. Untuk menguji melaksanakan aktivitas wawancara dengan mendalam (depth interview). Format wawancara yang penulis ajukan mengacu pada implementasi pemberian IMB (Izin Mendirikan Bangunan) di Kecamatan Bogor Timur.
1. Observasi
2. Dokumentasi
3. Wawancara

\section{Teknis Analisis Data}

a. Data Primer adalah data yang didapatkan dari hasil wawancara dan angket dibagikan kepada responden.

b. Data Sekunder yaitu data yang diambil dari Kantor Kecamatan Bogor Timur.

Dari permasalahan yang ada penulis mengemukakan hipotesis penelitian "Semakin efektif hubungan efektivitas kerja aparat kecamatan maka semakin baik pelayanan kepada masyarakat Kecamatan Bogor Timur". Sedangkan untuk 
penghitungan angka penafsiran dalam pengisian table frekuensi digunakan rumus WMS :

$\mathrm{M}=\sum \mathrm{fx} / \mathrm{n}$

Keterangan; $\mathrm{M}=$ Angka penafsiran

$$
\begin{aligned}
& \mathrm{f}=\text { Frekuensi } \\
& \mathrm{X}=\text { Bobot } \\
& \mathrm{n}=\text { Jumlah Sampel }
\end{aligned}
$$

Untuk menentukan kriteria penafsiran dilakukan dengan cara menghitung interval nilai, yaitu sebagai berikut :

$$
\mathrm{I}=5-1=4 / 5
$$$$
=0,8
$$

\section{Tabel 1}

Kriteria Penilaian terhadap Angka Penafsiran

\begin{tabular}{|c|c|c|}
\hline \multirow{2}{*}{ NO } & ANGKA & KRITERIA \\
& PENAFSIRAN & PENILAIAN \\
\hline 1. & $4,01-5,00$ & Selalu \\
2. & $3,01-4,00$ & Sering \\
3. & $2,01-3,00$ & Kadang- \\
4. & $1,01-2,00$ & kadang \\
5. & $00,01-1,00$ & Pernah \\
& & Tidak \\
& & Pernah \\
\hline
\end{tabular}

Sumber : Sugiyono, 2007

Sedangkan untuk menguji hipotesis dari penelitian ini digunakan rumus korelasi Korelasi Spearman Rank dengan rumus yaitu sebagai berikut :

$6 . \Sigma \mathrm{b} 1^{2}$

$\rho=1-$

$\mathrm{n}\left(\mathrm{n}^{2}-1\right)$

$\rho=$ koefesien korelasi spearman rank

Korelasi spearman rank digunakan mencari hubungan/pengaruh atau untuk menguji signifikansi hipotesis asosiatif bila masingmasing variabel yang dihubungkn berbentuk ordinal, dengan hipotesis yaitu :

$\mathrm{Ho}=0$ (Tidak terdapat hubungan antara efektivitas kerja aparat Kecamatan Bogor Timur dengan pelayanan kepada masyarakat)

Ha $\neq 0$ (Terdapat hubungan antara antara efektivitas kerja aparat Kecamatan Bogor Timur dengan pelayanan kepada masyarakat)

Sedangkan untuk menguji suginifikansi menggunakan uji $t$ dengan taraf kesalahan $5 \%$ : $\mathrm{r} \sqrt{\mathrm{n}-2}$

$\mathrm{t}=\sqrt{1-r^{2}}$

Hipotesis statistiknya adalah :

$\mathrm{Ho}=0$ (Tidak ada pengaruh)

$\mathrm{Ha} \neq 0$ (ada pengaruh).

Ketentuannya adalah bila $r$ hittung lebih kecil dari tabel maka Ho diterima dan Ha Ditolak. Tetapi sebaliknya bila $r$ hitung lebih besar dari t tabel (rho hit > $r$ tabel) ma $\mathrm{Ha}$ diterima. Untuk mengetahui harga $t$ signifikansi atau tidak maka perlu di bandingkan denga table $\mathrm{t}$ dengan taraf kesalahan 5\%.

\section{HASIL DAN PEMBAHASAN}

\begin{tabular}{|c|c|c|c|}
\hline No & Indikator & $\begin{array}{c}\mathrm{KP} \\
1\end{array}$ & KP2 \\
\hline 1 & $\begin{array}{l}\text { Keterbukaan dalam } \\
\text { pelayanan yang } \\
\text { diberikan oleh } \\
\text { aparat/petugas }\end{array}$ & 3,6 & Sering \\
\hline 2 & $\begin{array}{l}\text { Sistem pelayanan } \\
\text { yang sudah memadai }\end{array}$ & 3,9 & Sering \\
\hline 3 & $\begin{array}{l}\text { Melaksanakan tugas } \\
\text { sesuai peraturan } \\
\text { yang berlaku }\end{array}$ & 3,4 & Sering \\
\hline 4 & $\begin{array}{l}\text { Menyelesaikan tugas } \\
\text { sesuai tanggung } \\
\text { jawab pekerjaannya }\end{array}$ & 3,7 & Sering \\
\hline 5 & $\begin{array}{l}\text { Petugas } \\
\text { berkomitmen tepat } \\
\text { waktu }\end{array}$ & 3,6 & Sering \\
\hline 6 & $\begin{array}{l}\text { Petugas } \\
\text { mengedapankan } \\
\text { kepentingan } \\
\text { masyarakat dalam } \\
\text { melaksanakan } \\
\text { tugasnya }\end{array}$ & 3,4 & Sering \\
\hline 7 & $\begin{array}{l}\text { Aparat/petugas } \\
\text { mendengar dan } \\
\text { menindaklanjuti } \\
\text { aspirasi warga }\end{array}$ & 3,4 & Sering \\
\hline 8 & $\begin{array}{l}\text { Petugas } \\
\text { mempertimbangkan } \\
\text { aspirasi warga dalam } \\
\text { menyusun suatu } \\
\text { kebijakan }\end{array}$ & 3,3 & Sering \\
\hline
\end{tabular}

Dari hasil Analisis Data pada setiap Indikator maka diperoleh Rekapitulasi dari Setiap Indikator. 


\begin{tabular}{|c|c|c|c|}
\hline 9 & $\begin{array}{l}\text { Petugas menanggapi } \\
\text { setiap persoalan } \\
\text { yang ada } \\
\text { dimasyarakat }\end{array}$ & 3,4 & Sering \\
\hline 10 & $\begin{array}{l}\text { Petugas } \\
\text { membedakan status } \\
\text { sosial dalam } \\
\text { memberikan } \\
\text { pelayanan terhadap } \\
\text { masyarakat }\end{array}$ & 3,4 & Sering \\
\hline 11 & $\begin{array}{l}\text { Petugas } \\
\text { membedakan dari } \\
\text { segi suku, ras, dan } \\
\text { agama terhadap } \\
\text { masyarakat }\end{array}$ & 3,5 & Sering \\
\hline 12 & $\begin{array}{l}\text { Petugas adil } \\
\text { terhadap pelayanan }\end{array}$ & 3,5 & Sering \\
\hline 13 & $\begin{array}{l}\text { Petugas melayani } \\
\text { dengan ramah }\end{array}$ & 3,7 & Sering \\
\hline 14 & $\begin{array}{l}\text { Ruangan proses } \\
\text { pelayanan yang } \\
\text { sudah memadai }\end{array}$ & 3,6 & Sering \\
\hline 15 & $\begin{array}{l}\text { Proses pelayanan } \\
\text { sudah tepat waktu }\end{array}$ & 3,6 & Sering \\
\hline 16 & $\begin{array}{l}\text { Proses pelayanan } \\
\text { sudah terlayani } \\
\text { dengan baik }\end{array}$ & 4 & Sering \\
\hline 17 & $\begin{array}{l}\text { Kewajiban } \\
\text { masyarakat } \\
\text { melengkapi berkas } \\
\text { dengan lengkap dan } \\
\text { benar }\end{array}$ & $4 ., 3$ & Selalu \\
\hline & Jumlah & $\begin{array}{c}61 \\
3\end{array}$ & \\
\hline & Rata-rata & 3,6 & Sering \\
\hline
\end{tabular}

Nilai rata-rata dari 17 indikator adalah 3,6 dengan kriteria penilaian sering artinya dalam memberikan pelayanan kepada masyarakat aparat sering memberi kemudahan dan berlaku adil serta baik kepada warga.

\section{PEMBAHASAN}

Pelayanan yang dilakukan aparat pemerintah kepada masyarakat mempunyai dampak yang luas, salah satunya penyelenggaraan pemerintahan yang berjalan dengan baik sehingga dapat mendorong dinamika masyarakat untuk bergerak maju menyesuaikan dengan situasi dan tuntutan zaman. Pemenuhan kebutuhan masyarakat tersebut dapat dijadikan standar bagi aparat Pemerintah Kecamatan untuk mencapai efektivitas kerja dalam memberikan pelayanan kepada masyarakat, dengan memberi pelayanan prima, yaitu suatu pelayanan yang mengutamakan kepuasan pelanggannya.

1) Tanggapan pegawai/petugas terhadap kualitas pelayanan IMB dalam meningkatkan kualitas pelayanan di Kecamatan Bogor Timur

Adapun hasil dari analisis kualitas pelayanan IMB dalam meningkatkan kualitas pelyanan dikecamatan Bogor Timur, diketahui bahwa nilai terendah terletak pada indikator Petugas mempertimbangkan aspirasi warga dalam menyusun suatu kebijakan sebesar 3.3 dengan kriteria penafsiran sering, namun meski indikator ini paling rendah namun masih dalam garis ukuran sering yang dimana dapat disimpulkan bahwa indikator ini sering dilakukan oleh petugas pelayanan terhadap informan ataupun sasaran layanan. Sedangkan nilai tertinggi diperoleh pada indikator Kewajiban masyarakat melengkapi berkas dengan lengkap dan benar sebesar 4.3 dan dapat disimpulkan bahwa petugas sering sekali melakukan himbauan terhadap masyarakat tentang kewajiban masyarakat selaku sasaran pelayanan dalam melengkapi berkas dengan lengkap .

2) Pencapaian kualitas pelayanan IMB yang berada di Kecamatan Bogor Timur.

Kualitas pelaksanaan pelayanan izin mendirikan bangunan (IMB) pada kantor pelayanan terpadu kecamatan bogor timur, dinilai belum baik dilihat dari aspek penerapan etika birkokrasi, karena belum sepenuh hati dilakukan, belum mengutamakan kepuasan, dan belum 
sepenuhnya menjunjung kehormatan dan kejujuran.

Analisis kualitas pelayanan yang dilakukan di kecamatan Bogor Timur tentunya tidak terlepas dari proses manajemen yang dilakukan dalam struktur organisasi yang mencerminkan wewenang, tugas pokok, dan fungsi setiap bagianbagian yang ada dan bermuara pada kualitas pelayanan. Sampai sejauh mana kualitas pelayanan yang diberikan kepada pemohon IMB dapat dilihat dari aspek proses kepemilikan IMB itu sendiri. Aspek proses kepemilikan IMB akan diuraikan sebagai berikut.

\section{Aspek Proses Kepemilikan IMB}

Aspek proses kepemilikan IMB merupakan suatu proses interaksi, dimana satu pihak memberikan layanan dan dipihak lainnya membutuhkan layanan. Pada kondisi ini diharapkan terjadi keseimbangan sehingga antara pemberi pelayanan dan yang menerima layanan dapat menerima hasil dari interaksi tersebut.

Dalam penelitian ini untuk mengukur kualitas pelayanan kepada masyarakat pengguna jasa IMB oleh Dinas Perizinan Kabupaten Bantul dalam aspek proses kepemilikan IMB meliputi:

\section{Kesederhanaan}

Untuk mengetahui sejauh mana kesederhanaan pelayanan yang dilakukan oleh Dinas Perizinan Kabupaten Bantul terhadap masyarakat pemohon IMB, hal ini diukur dari tiga aspek:

a. Adanya kemudahan dalam pengurusan

Harapan masyarakat untuk mendapatkan kemudahan-kemudahan dalam pelayanan proses kepemilikan IMB belum dapat diwujudkan secara maksimal, hal ini disebabkan oleh berbagai faktor, yaitu faktor eksternal menyangkut persyaratan yang harus dipenuhi oleh pemohon IMB dan faktor internal yaitu menyangkut prosedur yang harus dilalui.

b. Kelancaran dalam Pengurusan

Mekanisme dan prosedur proses pengurusan IMB yang melewati proses cukup panjang mengakibatkan adanya celah bagi aparat untuk melakukan KKN. Terbukanya kesempatan menerima sogok dikarenakan seseorang aparat mempunyai kekuasaan tertentu yang tidak dimiliki orang lain seperti wewenang memberi izin. Berbagai cara untuk memperoleh uang sogok melalui memperlambat proses penyelesaian izin, mencari dalih dengan kurang lengkapnya dokumen, sibuk, sulit dihubungi atau dengan jurus sedang di proses.

c. Tidak Berbelit-belit

Proses pelayanan yang tidak berbelit-belit merupakan salah satu indikator pelayanan yang berkualitas. Sebagai suatu proses, pelayanan harus dapat berlangsung secara rutin dan berkesinambungan yang meliputi seluruh rangkaian kegiatan pelayanan dengan tidak memperpanjang jalur birokrasi dan alasan yang sengaja diciptakan.

Proses yang berbelit-belit dirasakan oleh masyarakat pemohon IMB apabila dihadapkan pada persyaratan administratif, dimana tahap ini melibatkan berbagai instansi untuk mengurus surat menyurat memakan waktu cukup lama dan sangat birokratis.

Dari hasil wawancara, 2 responden mengatakan adanya proses persyaratan kepemilikan IMB yang berbelit-belit. Selanjutnya 3 responden mengatakan bahwa tidak merasakan prosedur yang berbelit-belit. Dan 25 responden lainnya mengatakan tidak tahu menahu tentang prosedur pembuatan IMB.

Dapat disimpulkan bahwa proses berbelit-belit yang dirasakan oleh masyarakat disebabkan karena belum adanya penyederhanaan baik mengenai persyaratan maupun prosedur-prosedur yang harus dilalui oleh pemohon IMB.

Dilihat dari penjelasan diatas maka dapat dikatakan bahwa pencapaian kualitas pelayanan dalam pembuatan pmb di kecamatan bogor timur masih belum dikatakan maksimal dikarenakan masih banyak hal yang harus diperbarui lagi alur 
sistem izin itu sendiri yang harus dimaksimalkan.

3) Usaha-usaha yang dilaksanakan pemerintah di dalam meningkatkan pelayanan IMB.

Usaha pemerintah dalam peningkatan image pelayanan dimulai dengan diimplementasikannya UU Nomor 12 Tahun 2008 tentang Perubahan kedua atas UU Nomor 2 Tahun 2007 tentang Pembagian Urusan Pemerintahan antara Pemerintah, Pemerintah 2 Provinsi, Pemerintah Kabupaten/Kota, selanjutnya PP No. 41 Tahun 2007 mengenai Organisasi Perangkat Daerah, dan pada akhirnya melalui Mendagri (Menteri Dalam Negeri) dengan Permendagri No. 24 Tahun 2006 mengenai Penyelenggaraan Pelayanan Terpadu Satu Pintu serta Permendagri No. 20 Tahun 2008 mengenai Pedoman Organisasi dan Tata Kerja Unit Pelayanan Perizinan Terpadu di Daerah.

Meskipun setiap kelembagaan pemerintah telah mengadakan peningkatan dan perbaikan setiap tahunnya, akan tetapi masih saja dirasa ada yang kurang. Peningkatan kinerja menjadi salahsatu penyebab utama untuk memperbaiki kondisi birokrasi di Indonesia agar dapat memperikan pelayanan terbaiknya kepada masyarakat yang menjadi pelanggannya. Adanya evaluasi kerja dalam suatu organisasi menujukkan bahwa organisasi tersebut mulai berusaha untuk mengupayakan peningkatan kinerja yang optimal. Oleh karena itu, penilaian terhadap kinerja suatu organisasi sangat penting dilakukan karena dapat dipakai sebagai tolak ukur tingkat keberhasilan suatu organisasi dalam jangka waktu tertentu dan dapat dijadikan sebagai perbaikan atau peningkatan kinerja organisasi selanjutnya. Pemerintah melalui kebijakan yang tertuang dalam Peraturan Menteri Dalam Negeri No. 24 Tahun 2006 tentang Penyelenggaraan Pelayanan Terpadu Satu Pintu yang intinya meminta pemerintah daerah melakukan kegiatan seperti: a. Penyederhanaan sistem dan prosedur perizinan usaha

b. Pembentukan Lembaga Pelayanan Perizinan Terpadu Satu Pintu di daerah

c. Pemangkasan waktu dan biaya perizinan

d. Perbaikan sistem pelayanan

e. Perbaikan sistem informasi

f. Pelaksanaan monitoring dan evaluasi proses penyelenggaraan perizinan.

Dibentuknya Badan Pelayanan Perizinan Terpadu Kecamatan Bogor Timur dengan menimbang:

a. Bahwa dalam rangka meningkatkan pelayanan kepada masyarakat khususnya dibidang perizinan, maka perlu adanya sistem pemberian izin yang cepat, efisien dan terpadu.

b. Bahwa untuk mempercepat /memperlancar dan memberikan pelayanan terbaik kepada masyarakat dalam proses penerbitan perizinan di Kecamatan Bogor Timur, maka dipandang perlu menunjuk Kepala Badan Pelayanan Perizinan Terpadu Kecamatan Bogor Timur untuk dan atas nama Walikota Kota Bogor.

c. Bahwa berdasarkan pertimbangan sebagaimana dimaksud pada huruf a dan b diatas perlu ditetapkan Keputusan Walikota tentang penunjukan Kepala Badan Pelayanan Perizinan Terpadu Kecamatan Bogor Timur untuk menandatangani naskah/sertifikat bidang perizinan dan non perizinan di Kota Bogor.

4) Faktor-faktor yang mempengaruhi dalam peningkatan kualitas pelayanan di kecamatan Bogor Timur.

\section{Struktur Organisasi}

Struktur organisasi yang dimaksud disini bukanlah dalam perwujudan susunan organisasi, melainkan bagaimana pengaturan dan mekanisme kerjanya yang harus mampu menghasilkan layanan yang berkualitas. Karena organisasi merupakan suatu mekanisme maka perlu adanya daya dukung yang berfungsi memperlancar 
mekanisme itu, hal ini dapat dilihat dari: Tingkat kompleksitas organisasi, Tingkat desentralisasi, dan Formalisasi.

\section{Tingkat Kompleksitas Organisasi}

Untuk melihat bagaimana pengaruh tingkat kompleksitas terhadap kualitas pelayanan, akan diukur dengan:

a. Pembagian Departemen Dibawah Tanggung Jawab Seseorang dan Pengaruhnya Terhadap Kualitas Pelayanan.

Berdasarkan hasil pengamatan dan interview dengan responden, baik yang telah memiliki maupun yang sedang mengajukan permohonan kepemilikan IMB, sebagian besar diantara mereka berpendapat bahwa proses yang dilalui sangat prosedural hingga terasa bahwa pelayanan itu tidak mencerminkan pelayanan yang fleksibel sesuai dengan tuntutan suatu organisasi modern.

\section{Tingkat Desentralisasi}

Tingkat desentralisasi menujukkan sejauh mana kewenangan yang diberikan kepada bagian/seksi dalam ikut serta pada proses pengambilan keputusan menyangkut operasionalisasi organisasi. Untuk melihat sejauh mana tingkat desentralisasi akan diukur dari dua aspek:

a. Banyaknya personil yang punya wewenang terlibat dalam setiap tingkat pembuatan keputusan.

Keterlibatan personil dalam mengambil keputusan yang berkenaan dengan bidang tugasnya masing-masing telah dilimpahkan pada sub bagian dan bidang. Pada tataran ini apabila ada masalah yang timbul yang berhubungan dengan tugas suatu sub bagian, maka seluruh personil yang ada dalam sub bagian itu dilibatkan untuk mengambil langkahlangkah penyelesaiannya. Dilain pihak apabila ada suatu masalah yang menyangkut organisasi secara keluruhan, maka seluruh bidang yang ada dilibatkan dalam memecahkan persoalan.

b. Besarnya wewenang yang diberikan berkaitan dengan jenis urusan yang didelegasikan ke sub bagian yang lebih rendah.

\section{Formalisasi}

Untuk mengetahui sejauh mana pelaksanaan formalisasi dalam melaksanakan tugas pelayan IMB kepada masyarakat pemohon, diukur dari aspek:

a. Banyaknya jenis pekerjaan mempunyai prosedur tetap (Protap), alasan penetapannya dan terhadap kualitas pelayanan.

Pelaksanaan pekerjaan yang didasarkan pada prosedur tetap (Protap) didasarkan atas struktur organisasi dan tata kerja serta ketentuan-ketentuan lain yang berkaitan dengan kepemilikan IMB. Prosedur tetap (Protap) dilaksanakan dengan maksud agar setiap pemberian IMB kepada masyarakat benar-benar memiliki unsur ketepatan.

\section{Sarana dan Pra Sarana}

Sarana dan prasarana adalah salahsatu unsur penting dalam menunjang proses pelayanan. Sarana pelayanan yang dimaksud yaitu segala jenis perlengkapan kerja, peralatan dan fasilitas lain yang memiliki fungsi sebagai alat utama pelaksanaan pekerjaan. Ketersediaan sarana pelayanan pada suatu organisasi sangat berpengaruh terhadap upaya memberikan pelayanan terhadap masyarakat. Berbagai keluhan yang sering disampaikan oleh masyarakat dalam menerima pelayanan dari suatu organisasi, hal ini terkadang disebabkan oleh faktor ketersediaan sarana sehingga berdampak pada proses pelayanan menjadi tidak efisien dan lambat. Sejalan dengan hal tersebut, untuk melihat sejauh mana sarana dan prasarana yang tersedia yang berpengaruh terhadap kualitas pelayanan, diukur dari tigas aspek:

\section{Sarana kerja yang tersedia}

Dua kondisi ini tentu harus di-support oleh ketersediaan sarana yang memadai. Ketersediaan peralatan kerja telah mampu memberikan dukungan terhadap pelayanan proses kepemilikan IMB tetapi belum secara optimal, namun hal ini tidak merupakan kendala utama dalam memberikan pelayanan khususnya pelayanan yang bersifat administratif.

Fasilitas yang tersedia 
Ketersediaan fasilitas pelayanan juga memberikan dampak terhadap proses pelayanan yang memungkinkan masyarakat pengguna jasa dapat menerima layanan cepat, tepat dan murah. Seiring dengan kemajuan yang telah dicapai masyarakat, maka kebutuhan akan pelayanan semakin kompleks, sehingga dituntut adanya kualitas pelayanan sesuai dengan kebutuhan masyarakat.

Apabila dilihat dari fasilitas pelayanan yang tersedia serta kontibusi yang diberikan pada awal dari proses kepemilikan IMB tidak merupakan kendala untuk memberi dan menerima layanan.

Ketersediaan dana yang menunjang kegiatan pelayanan

Dari sisi anggaran di Tahun 2013, pelayanan administrasi perkantoran dan peningkatan sarana dan prasarana aparatur memperoleh jatah anggaran sebesar Rp. 180.761.200 dan Rp. 455.099.300,. dengan anggaran yang sebesar itu tentu saja dalam bidang sarana dan prasarana sudah lebih dari cukup.

\section{SUMBER DAYA MANUSIA}

\section{Jumlah Pegawai}

Jumlah pegawai bisa dikatakan masih belum cukup dikarenakan masih kurangnya tenaga pegawai.

\section{Kualitas Pegawai}

Untuk melihat kualitas pegawai diukur dari dua aspek:

a. Jenis pedidikan para pegawai Jenis pendidikan yang dimiliki oleh para pegawai memberikan pengaruh terhadap pekerjaan yang menjadi tangung jawabnya, karena tanpa adanya kesesuaian antara pekerjaan dengan jenis pendidikan maka tidak dapat dicapai hasil yang optimal. Pelayanan pada pemohon IMB tentunya tidak dapat dilaksanakan secara maksimal, sehingga berpengaruh terhadap kualitas pelayanan yang diberikan.

b. Tingkat pendidikan para pegawai

Tingkat pendidikan seseorang merupakan salah satu faktor yang memberikan kontribusi terhadap organisasi dalam rangka mencapai tujuan. Semakin banyak anggota organisasi yang berpendidikan tinggi semakin tinggi pula kemampuasn untuk melaksanakan tugas sehingga memungkinkan organisasi itu dapat mencapai tujuan yang telah ditetapkan. Para pegawai pendidikan rata-rata S1. Tingkat pendidikan ini sangat bersifat umum sehingga belum mampu memberikan kontribusi yang optimal terhadap beban tugas yang diemban Dinas Perizinan Kabupaten Bantul apabila berdasarkan struktur dan tata kerja yang ada sekarang.

\section{Implikasi Teoriris}

Oleh sebab itu ketika dikaitkan dengan teori, bahwa penelitian ini menunjukan salah satu faktor yang akan lebih memaksimalkan pelayanan perijinan.

Memberikan sumbangan bagi pengembangan Ilmu Pemerintahan, khususnya yang berkenaan dengan teori kualitas pelayanan ijin mendirikan bangunan yang ada di Kecamatan Bogor Timur, manajemen pelayanan dan pelayanan publik.

\section{Implikasi Praktis}

Penelitian ini memiliki implikasi langsung bagi petugas dan masyarakat dimana suatu proses pelayanan yang baik sangat dibutuhkan dalam usaha mencapai suatu tujuan pelayanan itu sendiri maupun dalam mengatasi masalah - masalah yang timbul dalam perjalanan pelayanan. Memberikan sumbangan bagi pengembangan Ilmu Pemerintahan, khususnyayang berkenaan dengan teori kualitas pelayanan, manajemen pelayanan dan pelayanan publik

\section{KESIMPULAN}

1) Pelaksanaan pemberian Izin Mendirikan Bangunan dilakukan dengan mengacu Keputusan Gubernur Provinsi Jawa Barat No. 76 Tahun 2000 tentang tata cara memperoleh IMB, IPB dan KMB di provinsi Jawa Barat dan peraturan Daerah Provinsi Jawa Barat Nomor 7 Tahun 2010 Tentang Bangunan Gedung. Kebijakan Pemberian Izin Mendirikan Bangunan pada 
dasarnya merupakan suatu kebijakan dalam rangka mewujudkan program perencanaan dan pembangunan Kota khususnya di wilayah Kecamatan Bogor Timur, namun dalam rangka mengendalikan pengembangan dan penggunaan tanah, wilayah kecamatan Bogor Timur sering terbentur masalah peruntukan sehingga kasus yang sering muncul adalah pemilik bangunan yang dalam mendirikan bangunan sering bertentangan dengan arah kebijakan tata ruang yang telah ditetapkan.

2) Faktor-faktor yang mempengaruhi pelaksanaan pemberian Izin Mendirikan Bangunan yaitu penetapan kebijakan yang masih belum sejalan dengan pelaksanaan yang ada, rendahnya tingkatan kesadaran masyarakat akan arti penting dan manfaat memiliki IMB, masih banyak dijumpai kegiatan pelanggaran pembangunan dan persoalan peruntukan bangunan yang terjadi pada masyarakat, yaitu munculnya bangunan-bangunan tanpa IMB dan bangunan-bangunan yang tidak sesuia peruntukannya yang akhirnya mengakibatkan terjadinya tindakan penegakan hukum melalui sanksi. Faktor keterbatasan sumber daya manusia manusia serta kurangnya tenaga profesional dalam memberikan pelayanan IMB kepada masyarakat di wilayah Kecamatan Bigor Timur serta mekanisme koordinasi yang belum optimal dalam pelaksanaanya.

3) Upaya-upaya dalam meningkatkan pelayanan IMB (Izin Mendirikan Bangunan), Pemerintah Daerah Kecamatan sudah melakukan berbagai rencana dalam meningkatkan kualitas pelayanan di kantor Kecamatan Bogor Timur seperti, Penyederhanaan prosedur dan sistem perizinan usaha, Membentuk Lembaga Pelayanan Perizinan Terpadu Satu Pintu di daerah, Perbaikan sistem pelayanan, Pemangkasan waktu dan biaya perizinan, Perbaikan sistem informasi, serta Pelaksanaan monitoring dan evaluasi proses penyelenggaraan perizinan

\section{Saran}

a) Hendaknya Sudin perizinan Bangunan Kota Administrasi Kota Bogor atau seksi Dinas perizinan Bangunan Kecamatan Bogor Timur secara terusmenerus melakukan sosialisasi berkaitan dengan syarat-syarat Izin Mendirikan Bangunan kepada masyarakat agar masyarakat jauh sebelumnya telah mempersiapkannya guna pengurusan Izin Mendirikan Bangunan.

b) Hendaknya pelayanan IMB dari lingkup Kecamatan Bogor Timur hingga Suku Dinas Kota Administrasi Kota Bogor harus membenahi masalah pegawai di perizinan karena dalam pelaksanaan pembangunan di wilayah Kecamatan Bogor Timur yang semakin pesat, maka mengharuskan adanya penambahan pegawai di bidang perizinan dan di pengawasan \& penertiban bangunan selain itu, dalam setiap Satuan Kerja Perangkat Daerah di bidang perizinan dan pengawasan \& penertiban bangunan harus memiliki tenaga profesional di bidang perizinan. Tenaga profesional dimaksud adalah berkaitan dengan kemampuan mengolah administrasi dan kemampuan teknis lapanga sesuai dengan disiplin keilmuan yang dimilikinya.Kemampuan pofesionalitas tersebut tentunya sangat berkaitan dengan pendidikan dari pegawai pada SKPD tersebut.

c) Hendaknya petugas di pengawasan dan penertiban bangunan lebih meningkatkan lagi pengawasan pelaksanaan pemberian IMB di Kecamatan Bogor Timur dalam rangka penertiban dari pelanggaran-pelanggaran izin yang dilakukan oleh pemilik bangunan.

d) Hendaknya pengawasan juga dilakukan oleh pihak eksternal, hal ini berkaitan jika ada pegawai di perizinan yang tidak menjalankan tugasnya sesuia dengan aturan yang berlaku, seperti oknum yang memberikan izin namun tidak sesuia dengan rencana tata ruang serta adanya pemungutan retribusi yang tidak sesuai dengan aturan yang berlaku. 
Abiding. 2010. Aspek-aspek kualitas pelayanan: Tujuh Prinsip NPS. Jakarta: Rajawali Press.

Barnard, Chaster I. 1996. Research design: efektivitas pelayanan. Yogyakarta: pustaka pelajar.

Boediono, 2012. Manajemen pelayanan publik. Konseptual indicator pada pelanggan. Yogyakarta: Pustaka pelajar.

Devi, Tania. 2014. Pengaruh kinerja pegawai terhadap kualitas pelayanan pada kantor Dinas Perizinan dan perumahan wilayah cibinong dinas cipta karya kabupaten Bogor, skripsi, program studi ilmu Manajemen Universitas Pakuan Kota Bogor.

Dwiyanto Agus, dkk. 2015. Reformasi Tata Pemerintahan dan Otonomi Daerah, Yogyakarta: Pusat Studi Kependudukan dan Kebijakan Universitas Gajah Mada.

Emerson, 1996. Efektivitas dalam Pelayanan. Malang: Yayasan Pembangunan Nasional \& CV. Sofa Mandiri. Gaebler, dan Osborn. 1995. Manajemen. Jakarta - Erlangga

Hasibuan. 1996. Ciri-ciri organisasi dan Efektivitas. Jakarta : Bumi Aksara.

Kasman. 2014. Implementasi Pengawasan Pemerintah Kota Medan Terhadap Izin Mendirikan Bangunan. Medan: Universitas Sumatera Utara

Kurniawan, 2005. Reformasi Pelayanan Publik: Teori, Kebijakan dan Implementasi. Jakarta: PT. Bumi Aksara.

Lupioadi, 2006. Manajemen pelayanan publik. Kualitas pelayanan dan pelayanan prima. Yogyakarta: Pustaka pelajar.

Moleong, Lexy J. 2010. Metode Penelitian Kualitatif. Bandung: Remaja Rosdakarya.

Namawi. 2001. Teknik Sampling untuk Survei dan Eksperimen. Rineka Cipta. Jakarta
Natsir. 2006. Metode Penelitian Suatu Pendekatan Proposal. Jakarta : Bumi Aksara.

Saefullah. 1999. Pengantar pelayanan publik (public service). Jakarta: Edisi Ketiga. Binarupa Aksara.

Sjamsuddin, Sjamsiar, 2011. Kepemerintahan \& Kemitraan. Malang: Yayasan Pembangunan Nasional \& CV. Sofa Mandiri.

Steers, 1989. Organisasi dan Manajemen: Teori, fungsi dan pelayanan. Jakarta: PT. Bumi Aksara.

Sugiyono. 2012. Metode Penelitian Kuantitatif Kualitatif dan R\&D, Alfabeta.

Supranto, J. 2014. Teknik Sampling untuk Survei dan Eksperimen. Rineka Cipta. Jakara

Sutedi, Adrian. 2011. Definisi Izin Mendirikan Bangunan. Penerbit PT Gramedia Pustaka Utama,Jakarta

Yudha, Agus Dwi. 2016. Implementasi Pemungutan Retribusi Izin Mendirikan Bangunan Sebagai Sumber Pendapatan Asli Daerah Kota Depok. Depok: Universitas Indonesia

Wijaya, Adam I Indra. 2000. Sistem-sistem organisasi dan manajemen. Jakarta: PT, RajaGrafindo Persada

\section{Dokumen}

Undang-undang Nomor 32 Tahun 2004 tentang Pemerintah Daerah

Undang-undang Nomor 53 Tahun 2010 tentang Disiplin Pegawai Negeri sipil 